US Army Corps

of Engineers ${ }_{\circledast}$

Engineer Research and

Development Center

Integrated Climate Assessment for Army Enterprise Planning

\title{
Heating and Cooling Cost Model User's Guide
}

Byron M. Garton

July 2019

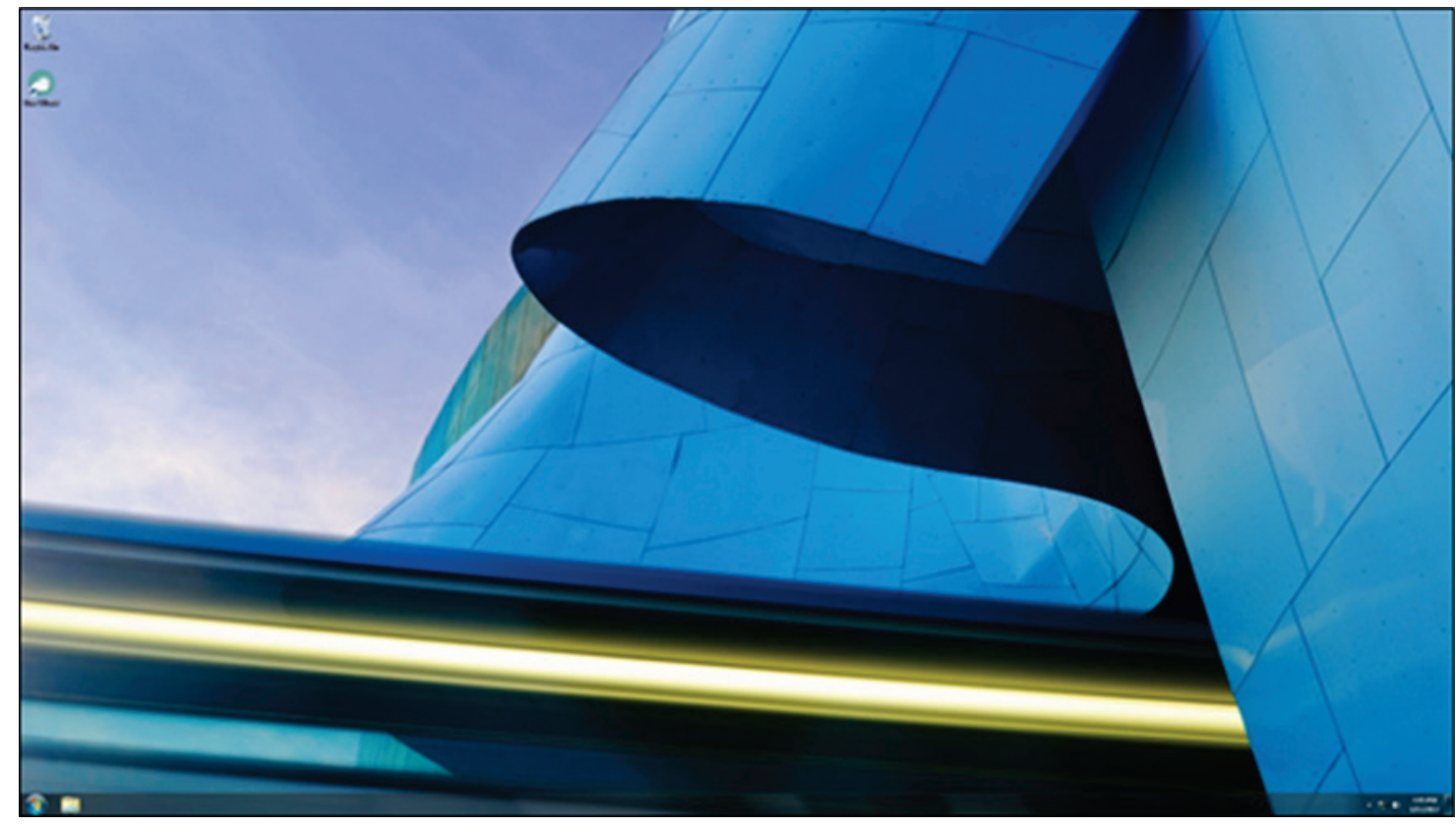


The U.S. Army Engineer Research and Development Center (ERDC) solves the nation's toughest engineering and environmental challenges. ERDC develops innovative solutions in civil and military engineering, geospatial sciences, water resources, and environmental sciences for the Army, the Department of Defense, civilian agencies, and our nation's public good. Find out more at www.erdc.usace.army.mil.

To search for other technical reports published by ERDC, visit the ERDC online library at http://acwc.sdp.sirsi.net/client/default. 


\title{
Heating and Cooling Cost Model User's Guide
}

\author{
Byron M. Garton \\ Information Technology Laboratory \\ U.S. Army Engineer Research and Development Center \\ 3909 Halls Ferry Road \\ Vicksburg, MS 39180-6199
}

Final report

Approved for public release; distribution is unlimited.

\author{
Prepared for U.S. Army Corps of Engineers \\ Washington, DC 20314-1000 \\ Under Project 402188 Integrated Climate Assessment for Army Enterprise Planning
}




\section{Abstract}

The Heating and Cooling Cost Model attempts to predict the future heating and cooling costs of occupied structures on Department of Defense (DoD) installations. These installations depend on a secure, reliable, and abundant supply of energy in order to accomplish their missions. Predicting the potential effect of climate change on heating and cooling costs is essential to maintaining optimal force stationing and readiness.

This document describes the process of executing the Heating and Cooling Cost Model, as it exists at the time of this writing, within the common computational environment established under the software integration effort of the Integrated Climate Assessment for Army Enterprise Planning work package.

DISCLAIMER: The contents of this report are not to be used for advertising, publication, or promotional purposes. Citation of trade names does not constitute an official endorsement or approval of the use of such commercial products. All product names and trademarks cited are the property of their respective owners. The findings of this report are not to be construed as an official Department of the Army position unless so designated by other authorized documents. 


\section{Contents}

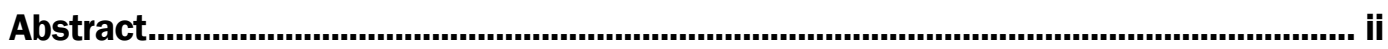

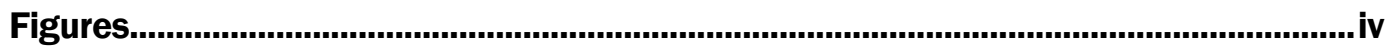

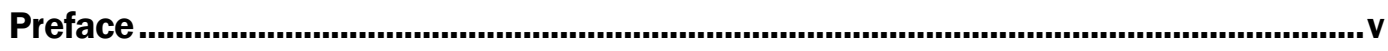

1 Introduction ......................................................................................................... 1

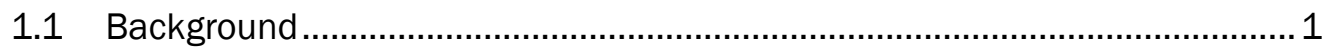

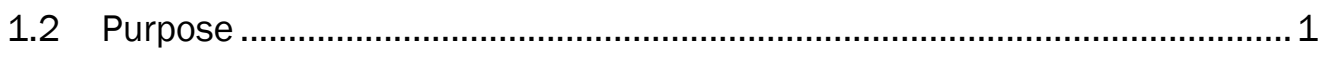

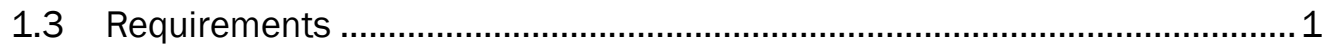

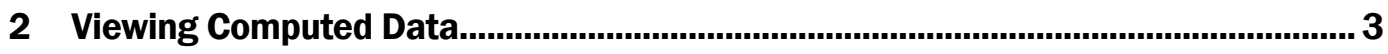

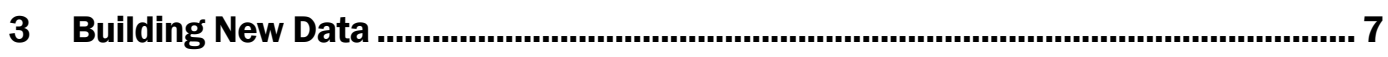

4 Known Issues and Limitations ….................................................................10

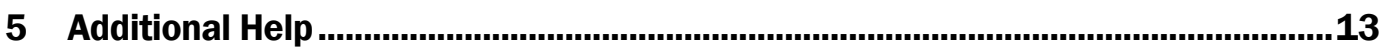

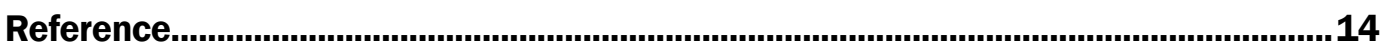

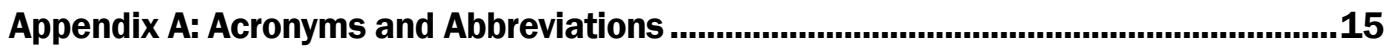

Report Documentation Page 


\section{Figures}

\section{Figures}

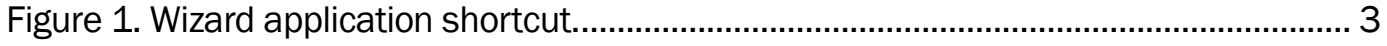

Figure 2. Heating and Cooling Cost Model icon. ............................................................... 4

Figure 3. Heating and Cooling Cost Model first screen. ....................................................... 4

Figure 4. Heating and Cooling Cost Model second screen. ................................................ 5

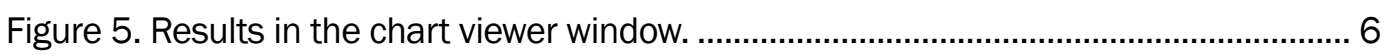

Figure 6. Heating and Cooling Cost Model final screen. ..................................................... 7

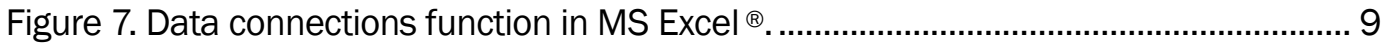




\section{Preface}

This research was conducted for the U.S. Engineer Research and Development Center-Construction Engineering Research Laboratory (ERDC-CERL) under Project 402188, Integrated Climate Assessment for Army Enterprise Planning. The Technical Monitor was Dr. James D. Westervelt of ERDC-CERL.

The work was performed by the Information Technology Laboratory (ITL), Scientific Software Branch (SSB), of the Computational Science and Engineering Division (CSED). At the time of publication, Mr. Timothy W. Dunaway was Chief of the SSB, Dr. Jerrell R. Ballard was Chief of the CSED, and Dr. Robert M. Wallace was the Technical Director. The Deputy Director of ERDC-ITL was Ms. Patti S. Duett, and the Director was Dr. David A. Horner.

COL Ivan P. Beckman was the Commander of ERDC, and Dr. David W. Pittman was the Director. 


\section{Introduction}

\subsection{Background}

The Heating and Cooling Cost Model attempts to predict the effect of climate change on the cost of heating and cooling occupied structures on Department of Defense (DoD) installations. If climate change results in a generally warmer climate, installations in cooling-dominated locations would be expected to experience increased cooling loads and possibly reduced heating loads. This will most likely result in increased electrical (cooling) requirements and possibly reduced fossil fuel (heating) requirements. Installations in heating-dominated areas might be expected to experience reduced heating requirements along with a possible increase in cooling requirements. The calculated heating and cooling cost is intended to be utilized in other force stationing analysis applications as a Military Value Analysis (MVA) attribute.

\subsection{Purpose}

This model makes use of a common computational environment and a user assistance application that were implemented as part of the Software Integration effort within the Integrated Climate Assessment for Army Enterprise Planning work package. The virtual environment will be referred to throughout this document as the Virtual Machine or VM, and the user assistance application will be referred to as the Wizard. For more information about the Software Integration effort, the virtual environment, and the user assistance application, refer to the Analytical Model Integration Methods Technical Report listed in the references section of this document.

Executing the model is a multiple step process that requires using MS Excel ${ }^{\circledR}$ and an internet browser. Each step for viewing and building data sets is thoroughly documented in the following sections to limit user confusion and ensure accurate results.

\subsection{Requirements}

Software requirements for the Heating and Cooling Cost Model include MS Excel ${ }^{\circledR}$ version 2013 or higher. Data collection prior to model execution requires an internet connection and internet browser. 
A working knowledge of Microsoft Office products is recommended as well as a basic understanding of accessing websites and downloading files from the internet. 


\section{Viewing Computed Data}

Pre-built dataset viewing is available to end users by accessing the model from within the Wizard application. The Wizard is accessible from the Integrated Climate Assessment for Army Enterprise Planning VM by clicking the shortcut located on the desktop (Figures 1-3).

Figure 1. Wizard application shortcut.

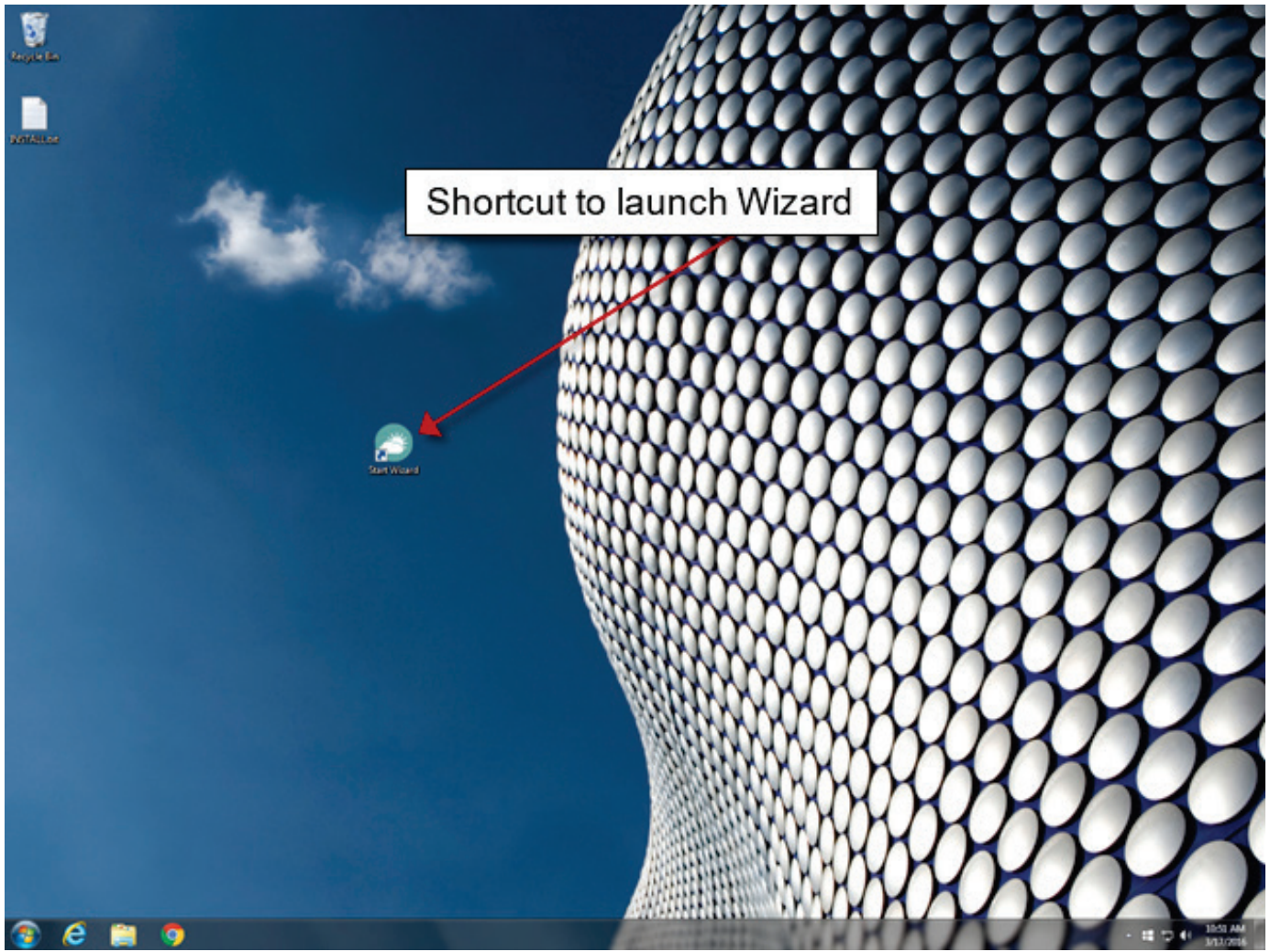


Figure 2. Heating and Cooling Cost Model icon.

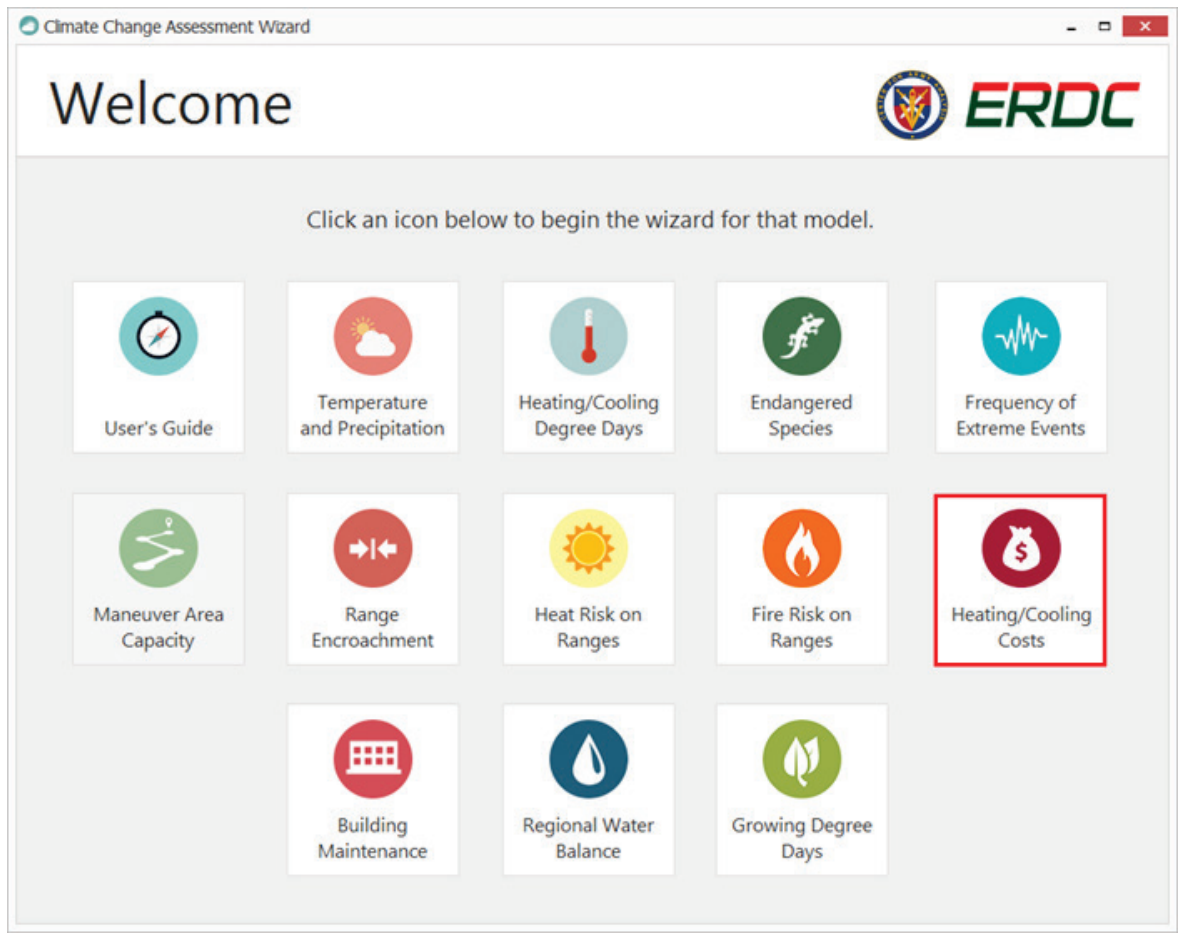

Figure 3. Heating and Cooling Cost Model first screen.

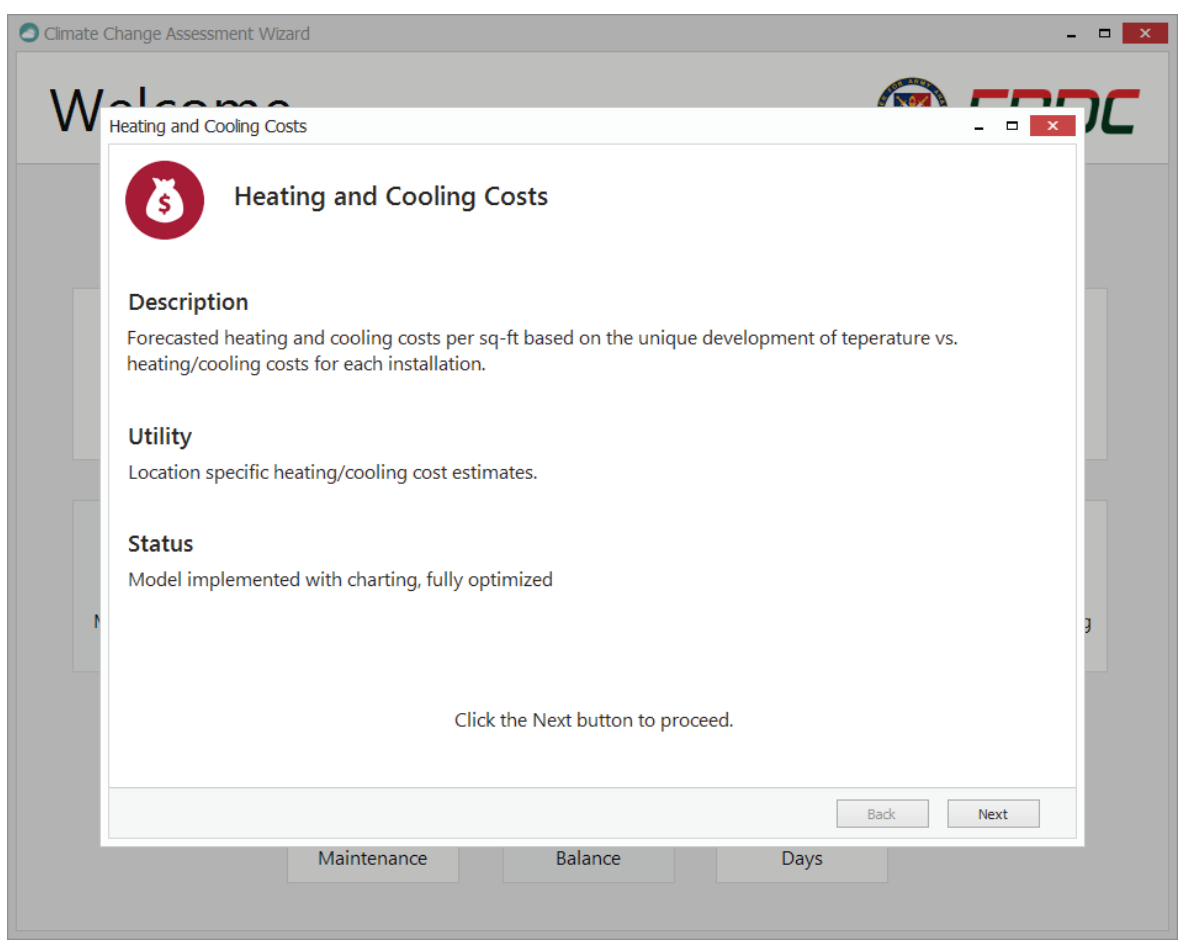

The second screen within the model (Figure 4) allows the end user to view the datasets in graphical or tabular mode. Users can choose the desired view type from the View drop down combo box. Options within this box 
are Graphs and Tabular. Graphs displays the data as standard line graphs while Tabular displays the data in a table layout within an MS Excel ${ }^{\circledR}$ spreadsheet.

Figure 4. Heating and Cooling Cost Model second screen.

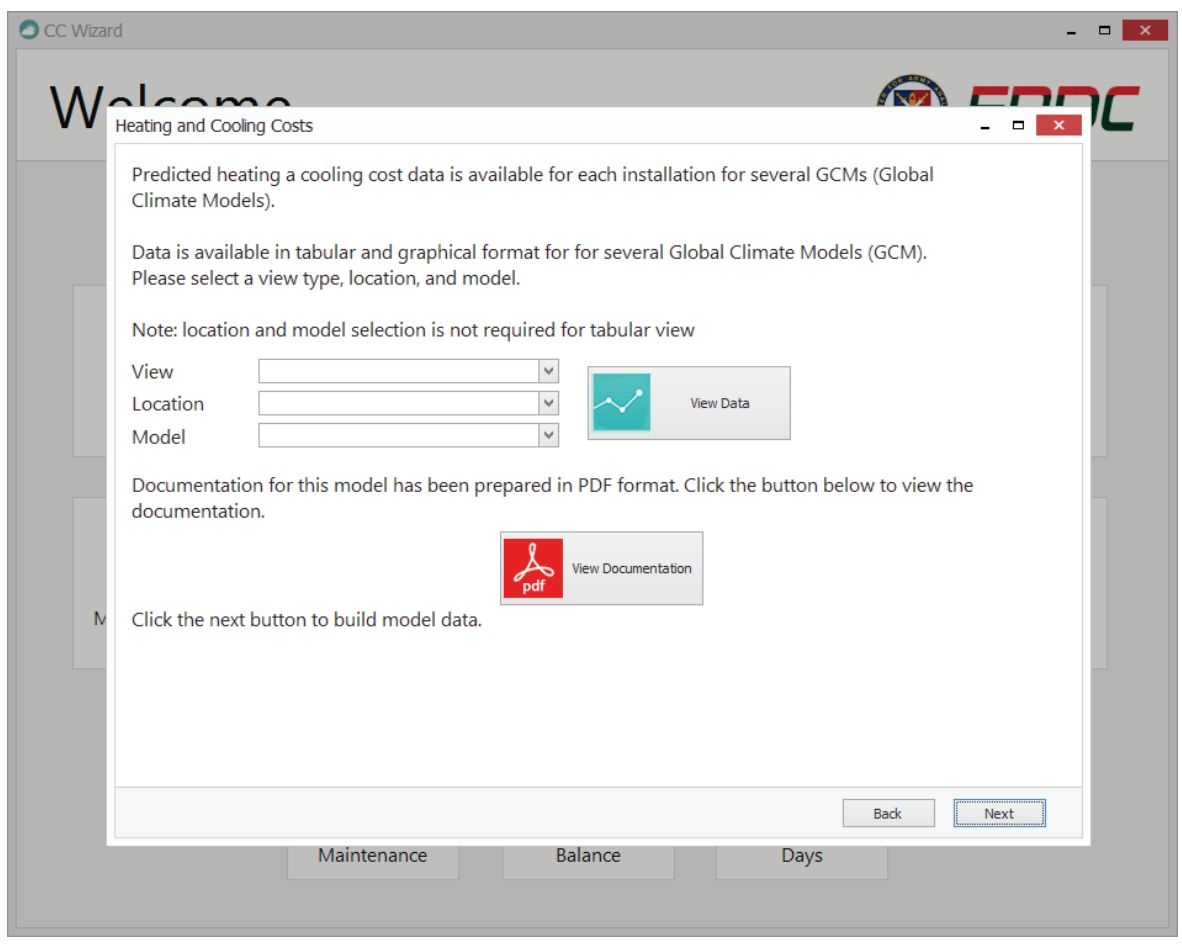

Next, choose a General Circulation Model (GCM) and Representative Concentration Pathway (RCP) type from the drop down combo box to filter only data related to that GCM/RCP. At the time of publication, there are ten GCMs within the dataset for this model. RCP 2.6, 4.5, and 8.5 were chosen to represent lower bound, middle, and upper bounds for each GCM. Each GCM contains these RCPs, with the exception of CNRM-CM-5 and GFDL-CM3.

Finally, choose a DoD location from the drop down box to filter only data associated with a particular location. Once all three of the choices are made, click the View Data button to launch the chart viewer window. 
Figure 5. Results in the chart viewer window.

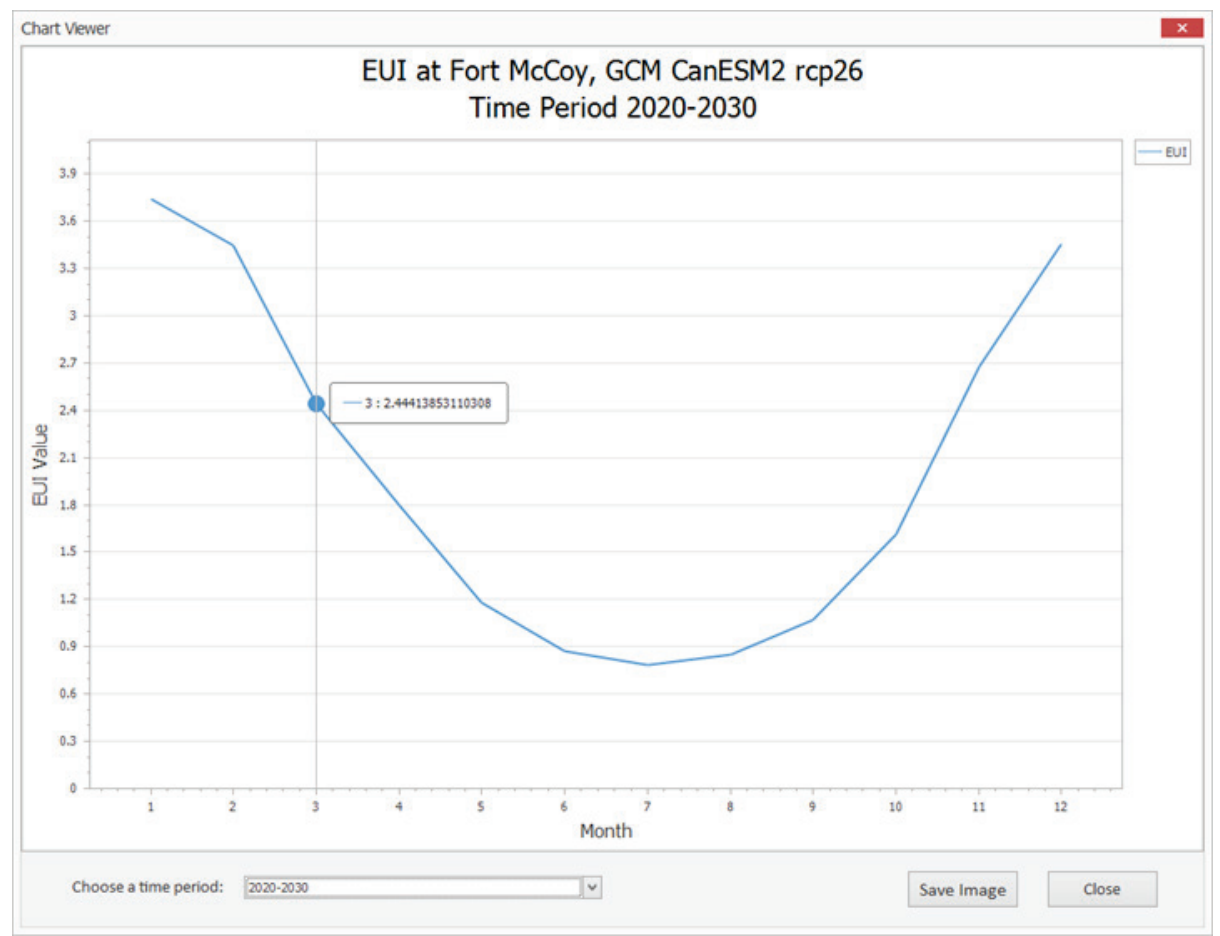

The average Energy Use Index (EUI) is plotted as a line graph with the average EUI value on the $\mathrm{Y}$-axis, and 12 months plotted on the $\mathrm{X}$-axis. The user can change the charted values by choosing a 10-year epoch up to 2100 from the drop down box near the bottom left of the window. Upon selecting an epoch, the data will automatically filter to include 12 months of average values over the chosen 10-year period.

Charts may be saved to the user's computer by clicking the Save Image button near the bottom right of the window. The resulting file is saved to a location of the user's choosing in the universal Joint Photographic Experts Group (JPEG) image file format. 


\section{Building New Data}

New datasets are built within the model's Wizard interface on its final screen. On this screen there are instructions and a button that starts the data building process. Output from the build process is displayed in the box below the button (Figure 6).

Figure 6. Heating and Cooling Cost Model final screen.

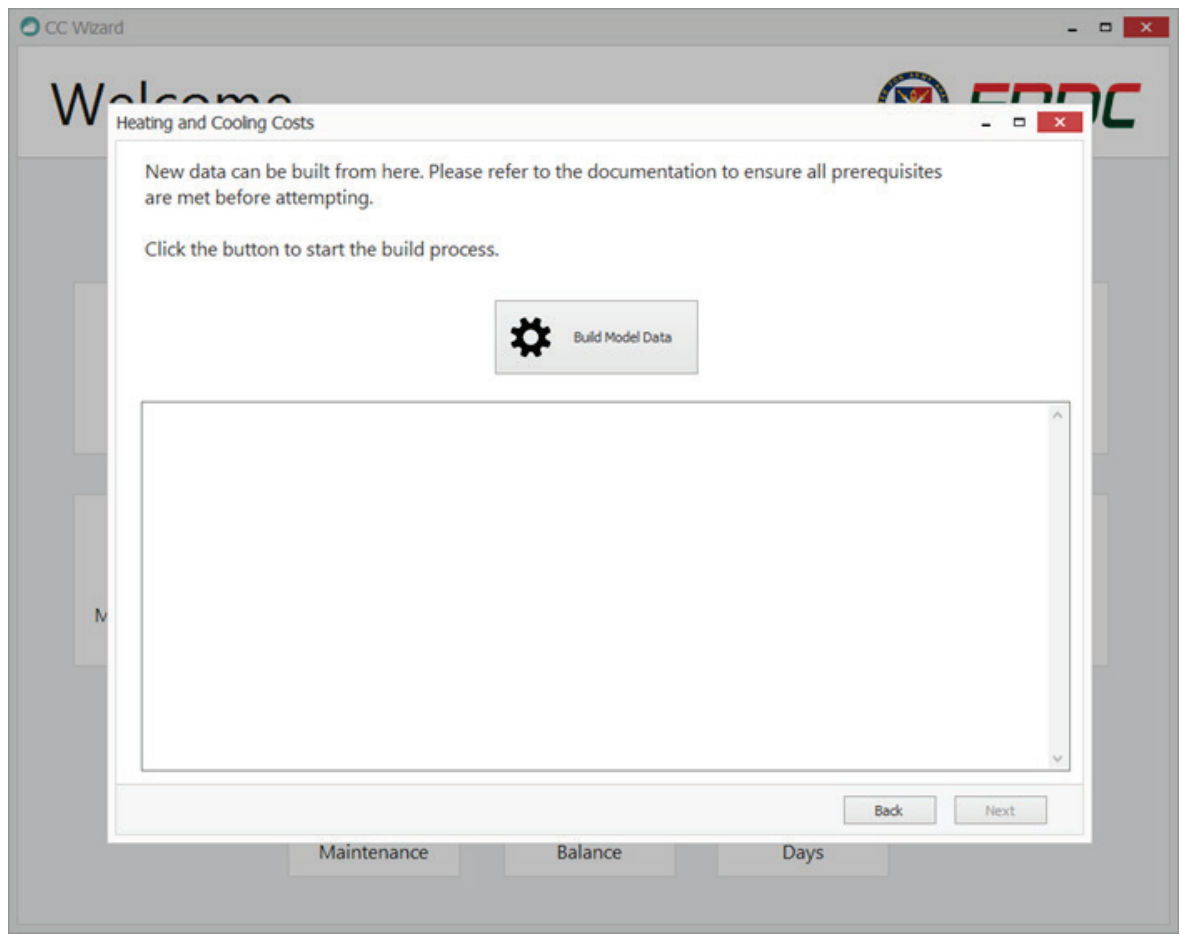

Before attempting the build process, there are a few prerequisites that must be verified.

First, the build process requires historical inputs to exist for each location. These inputs also have their own build process. The local path to these inputs on the VM is $\mathrm{C}: \backslash$ Models $\backslash$ Heating-Cooling-Cost $\backslash$ Historic Output. Inside that folder there are macro-enabled Microsoft MS Excel ${ }^{\circledR}$ workbooks that are used to build the historical inputs for each location. The reason they are mentioned here is in case a user wants to view the historical data; however, under no circumstances should these files be modified. Simply ensure these file exist prior to running the build process.

Second, the local folder $\mathrm{C}: \backslash$ Models $\backslash T$ emp-PrecipProjections $\backslash$ output $\backslash$ Month $l_{Y} \backslash$ Summary must be populated with 
future climate data stored in comma separated values (CSV) files for multiple GCMs prior to attempting the build process. Check this folder and ensure those files exist. If the files do not exist, they must be built using another process. Please refer to the documentation for the Temperature and Precipitation Model for instructions on how to build execute that model to produce the required data files.

Lastly, the future output data is placed in a folder with the following local path: C: $\backslash$ Models $\backslash$ Heating-Cooling-Cost $\backslash$ Future Output. This folder must be emptied prior to running the build process to ensure the integrity of the output data.

It should be noted that the build process can be quite lengthy, and patience should be observed. Also, monitor the output box during execution to recognize any repeating errors that may indicate a missing prerequisite.

As mentioned previously, historical data has already been processed and should not need to be reprocessed for the current locations that are being analyzed. However, this process will be required for new locations. The following paragraph describes the steps for processing historical data for new locations.

Historical data for each desired installation must be obtained from the Army Energy and Water Reporting System (AEWRS) by logging into the system at http://army-energy.hqda.pentagon.mil/ and from the National Climatic Data Center (NCDC) website available at http://www7.ncdc.noaa.gov/CDO/cdoselect.cmd?datasetabbv=GSOD\&resolution=40. Data for installation square footage, energy usage, and Global Surface Summary of the Day (GSOD) weather data must be downloaded and saved to these folders on the VM in the CSV file format:

- C: Models $\backslash$ Heating-Cooling-Cost\Data \SqFt Files

- C: $\backslash$ Models $\backslash$ Heating-Cooling-Cost\Data\Utilities Files

- C:\Models \Heating-Cooling-Cost\Data\GSOD Weather Data

A template file located at $\mathrm{C}: \backslash$ Models $\backslash$ Heating-CoolingCost $\backslash$ Historic Output $\backslash$ Template.xlsm must be used to import and process the data for new installations. This file contains MS Excel ${ }^{\circledR}$ data 
connections on each tab that must be refreshed and pointed to the new downloaded data files (Figure 7).

Figure 7. Data connections function in MS Excel ${ }^{\circledR}$.

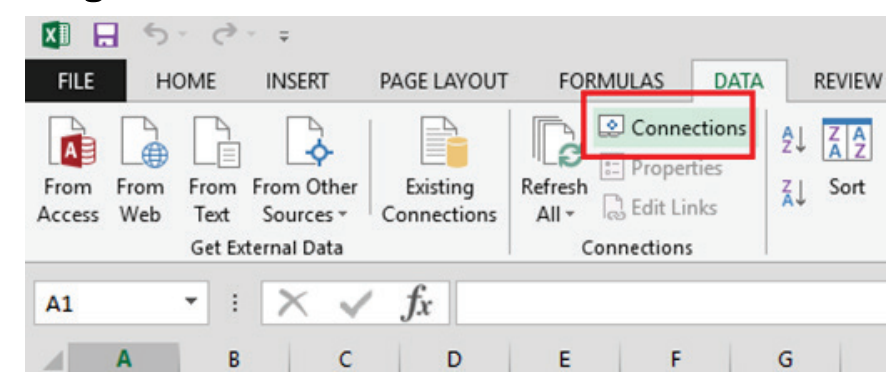

Also, on each tab inside this file there are buttons that are required to be clicked to run Visual Basic for Applications (VBA) code that parses, averages, and formats the newly refreshed data. There are buttons for calculating Million British Thermal Units (MMBTU), Kilo Square Feet (KSF), Weather, and EUI. Only installations that have future weather data available from the Temperature and Precipitation Model can be evaluated by the Heating and Cooling Costs Model. If additional locations are required that do not have future weather data already processed, then those locations must be processed through the Temperature and Precipitation Model prior to attempting to process them through this model. Refer to the documentation for the Temperature and Precipitation Model for instruction on how to process those locations. 


\section{Known Issues and Limitations}

For purposes of the study, a number of significant, simplifying assumptions were employed in our analysis ${ }^{*}$, including:

- Consideration was limited to historic dry bulb temperatures (DBT) and projections of DBT data as influenced by climate change. Historic or projected dew point temperature (DPT) data were not considered. Dew point temperatures are a measure of absolute humidity levels, and when used in conjunction with DBT, are used to determine the relative humidity levels of air. Moisture content of air has a major impact on cooling energy requirements, such that buildings in humid areas (such as the southeastern United States) require significantly more cooling energy to maintain comfort conditions than comparable buildings in semiarid regions (e.g., the southwestern United States) at similar ambient DBTs.

- Historic monthly average temperature data significantly simplified the hour-by-hour recorded temperatures over a month down to a single monthly average temperature and therefore, were not considered. Obviously, real temperatures follow a diurnal cycle and can fluctuate widely over the course of any given day and throughout the month. A day or month with widely fluctuating temperatures (i.e., a large standard deviation) can be expected to have greatly differing heating and cooling requirements than a day or month with a similar daily or monthly average temperature but less overall fluctuation (i.e., a smaller standard deviation) about the mean temperature.

- Also not considered were other climate factors such as historic and projected solar insolation, cloud cover, precipitation levels, or wind patterns. Although these historic data are readily available, projections of these data into the future are highly speculative and analyses dependent upon such projections would only add to uncertainty levels.

- Although historic installation data for conditioned building space was considered in the analyses to develop installation-specific EUI characteristic curves, the final product (a time series of projected installation EUI) is reported independently of installation building

\footnotetext{
* Miller, James P. Isabel H. Kim, David M. Underwood, and Melanie D. Johnson. In Prep. Integrated Climate Assessment for Army Enterprise Planning. Climate Change Impacts on Installation Energy. Projecting Climate Change Impacts on Installation Energy. Champaign, IL: U.S. Engineer Research and Development Center
} 
space numbers. This will allow Army planners to apply our projected EUI numbers to their own projections of installation square footage to project future energy requirements.

- The team's analysis made no attempt to consider or account for any increased penetration of installations' air conditioning requirements. It is almost certain that air conditioning penetration will increase, especially in regions which currently have relatively low cooling loads but which are projected to experience significant warming in future years. Nevertheless, penetration of air conditioning is often driven not only by climate conditions but also by policies and regulations which can be quite difficult to predict.

- Most Army installations are exhibiting trends of reduced EUIs as they respond to various statutes, Executive Orders, Service policies and other pressures to improve their overall energy efficiency and meet energy reduction targets. Nevertheless, even though it is apparent that many Army installations have had historic EUI reductions over time, it is difficult to project those trends into the distant future. Therefore, the team assumed no significant future change in the energy efficiencies of installations' building inventory due to improved building technologies, replacement of old, and inefficient buildings with new, efficient buildings or operational efficiencies which were independent of local climate characteristics.

- The team assumed no significant change in the mix of energy sources used to heat and cool the installation. For example, the fact was not considered that an installation currently using both propane (a relatively expensive energy source) and natural gas (a comparatively inexpensive energy source) for heating might migrate over time towards more use of natural gas and less dependence on propane. Unless an installation showed a clear historic trend of moving towards greater reliance on natural gas and less use of propane, for example, it was assumed that current usage patterns would persist.

- The team did not account for the possibility that an installation's energy source profile might shift in other ways over time. For example, an installation might construct a micro grid and install cogeneration capacity to offset a portion of its current purchased utility requirements. Such a move would often have the effect of increasing natural gas usage while reducing consumption of purchased electrical energy.

- Although renewable energy capacity at Army installations will likely increase in the future, the team did not know how to project future 
penetration of these technologies into the Army. Therefore, the expanded use of renewable energy sources such as on-site photovoltaics or wind energy, solar thermal, geothermal, or biomass energy which would reduce a portion of an installation's current purchased utility requirements was not considered.

- The team did not consider any change in mission activities which would affect installation energy requirements independently of local climate conditions. For example, the possibility that a given installation might gain (or lose) a large energy consumer such as an industrial operation, a data center, a simulator mission, etc., at some point in the future was not considered.

- The team avoided projections of future installation energy costs because there are too many unknowns in the unit cost of energy. 


\section{Additional Help}

Additional questions or concerns should be directed to the Program Manager (PM) of the Integrated Climate Assessment for Army Enterprise Planning program.

Paul M. Loechl

ERDC-CERL

Paul.M.Loechl@usace.army.mil

217-373-5892

Marty Garton

ERDC-ITL

Byron.m.garton@usace.army.mil

601-634-2888 


\section{Reference}

Garton, B. M. 2019. Analytical Model Software Integration Methods. ERDC/ITL SR-194. Vicksburg, MS: Information Technology Laboratory (ITL) - U.S. Engineer Research and Development Center. 


\section{Appendix A: Acronyms and Abbreviations}

\begin{tabular}{|c|c|}
\hline AEWRS & Army Energy and Water Reporting System \\
\hline CSV & Comma Separated Values \\
\hline DoD & Department of Defense \\
\hline DBT & Dry Bulb Temperature \\
\hline DPT & Dew Point Temperature \\
\hline ERDC & Engineer Research and Development Center \\
\hline ERDC-CERL & $\begin{array}{l}\text { Engineer Research and Development } \\
\text { Center- Construction Engineering Research } \\
\text { Laboratory }\end{array}$ \\
\hline ERDC-ITL & $\begin{array}{l}\text { Engineer Research and Development } \\
\text { Center- Information Technology Laboratory }\end{array}$ \\
\hline EUI & Energy Use Index \\
\hline GCM & Global Circulation Model \\
\hline GSOD & Global Surface Summary of the Day \\
\hline JPEG & Joint Photographic Experts Group \\
\hline KSF & Kilo Square Feet \\
\hline MMBTU & Million British Thermal Units \\
\hline MVA & Military Value Analysis \\
\hline NCDC & National Climatic Data Center \\
\hline NSN & National Supply Number \\
\hline OMB & Office of Management and Budget \\
\hline
\end{tabular}




$\begin{array}{ll}\text { PM } & \text { Program Manager } \\ \text { RCP } & \text { Representative Concentration Pathway } \\ \text { SAR } & \text { Same As Report } \\ \text { SF } & \text { Standard Form } \\ \text { VBA } & \text { Visual Basic for Applications } \\ \text { VM } & \text { Virtual Machine }\end{array}$




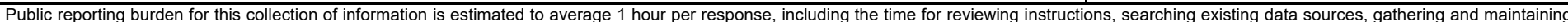

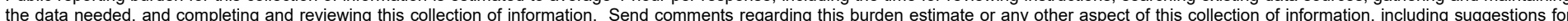

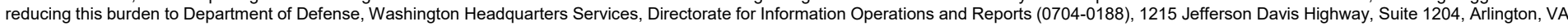

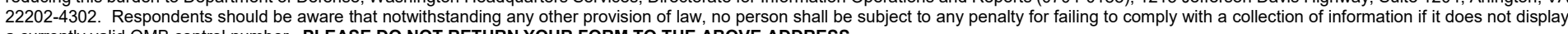
a currently valid OMB control number. PLEASE DO NOT RETURN YOUR FORM TO THE ABOVE ADDRESS.

\begin{tabular}{l|l|l} 
1. REPORT DATE (DD-MM-YYYY) & 2. REPORT TYPE & 3. DATES COVERED (FrOm - To)
\end{tabular} July 2019 4. TITLE AND SUBTITLE Final

Heating and Cooling Cost Model User's Guide 5a. CONTRACT NUMBER

Heating and Cooling Cost Model User's Guide

5b. GRANT NUMBER

5c. PROGRAM ELEMENT NUMBER

\section{AUTHOR(S)}

Byron M. Garton

5d. PROJECT NUMBER

402188

5e. TASK NUMBER

5f. WORK UNIT NUMBER

8. PERFORMING ORGANIZATION REPORT NUMBER

ERDC/ITL SR-19-11

Information Technology Laboratory

U.S. Army Engineer Research and Development Center

3909 Halls Ferry Road

Vicksburg, MS 39180-6199

9. SPONSORING / MONITORING AGENCY NAME(S) AND ADDRESS(ES)

U.S. Army Corps of Engineers

Washington, DC 20314-1000

12. DISTRIBUTION / AVAILABILITY STATEMENT

Approved for public release; distribution is unlimited

13. SUPPLEMENTARY NOTES

\section{ABSTRACT}

The Heating and Cooling Cost Model attempts to predict the future heating and cooling costs of occupied structures on Department of Defense (DoD) installations. These installations depend on a secure, reliable, and abundant supply of energy in order to accomplish their missions. Predicting the potential effect of climate change on heating and cooling costs is essential to maintaining optimal force stationing and readiness.

This document describes the process of executing the Heating and Cooling Cost Model, as it exists at the time of this writing, within the common computational environment established under the software integration effort of the Integrated Climate Assessment for Army Enterprise Planning work package.

\section{SUBJECT TERMS}

Climatic changes--Forecasting

Degree days

Buildings--Environmental engineering

Buildings--Heating--Costs
Buildings--Cooling--Costs

Buildings-- Dwellings--Air conditioning--

Costs

Military bases

\section{SECURITY CLASSIFICATION OF:}

\section{a. REPORT}

Unclassified

\section{b. ABSTRACT}

Unclassified
17. LIMITATION OF ABSTRACT c. THIS PAGE

Unclassified
18. NUMBER OF PAGES

24 19a. NAME OF RESPONSIBLE PERSON

19b. TELEPHONE NUMBER (include area code) 